DOI: https://doi.org/10.47405/mjssh.v6i7.836

\begin{tabular}{|c|c|}
\hline m & Malaysian Journal of Social Sciences and Humanities (MJSSH) \\
\hline Malaysian Journal of & Volume 6, Issue 7, July 2021 \\
\hline $\begin{array}{l}\text { Humantites } \\
\text { (MJ - SSH) }\end{array}$ & e-ISSN : 2504-8562 \\
\hline & $\begin{array}{c}\text { Journal home page: } \\
\text { www.msocialsciences.com }\end{array}$ \\
\hline
\end{tabular}

\title{
Keharmonian Kaum Berasaskan Sunnah: Kajian Terhadap Piagam Madinah
}

\author{
Helimy bin Aris' ${ }^{1}$ Amran Abdul Halim¹, Nari Muslim² \\ ${ }^{1}$ Fakulti Pengajian Quran dan Sunnah, Universiti Sains Islam Malaysia (USIM) \\ ${ }^{2}$ Pusat Pengajian Citra, Universiti Kebangsaan Malaysia (UKM) \\ Correspondence: Nazri Muslim (nazrim@ukm.edu.my)
}

\begin{abstract}
Abstrak
Masyarakat yang terdiri daripada pelbagai latar belakang sosial sering terdedah kepada konflik. Hal ini boleh menimbulkan isu seperti diskriminasi, pergaduhan, peperangan, penindasan dan sebagainya. Oleh sebab itu, kesepaduan sosial memainkan peranan penting untuk mencapai keharmonian dalam masyarakat majmuk. Yathrib (nama Madinah sebelum berlakunya peristiwa hijrah) umpamanya, terpahat dalam sejarah peradaban Semenanjung Tanah Arab sebagai 'kawasan konflik' kerana pergaduhan dan peperangan berterusan antara kaum Aus dan Khazraj. Nabi Muhammad SAW selaku ketua negara telah menggubal Piagam Madinah dalam usaha mengurus penduduk Madinah yang berbeza kaum, bahasa, agama dan adat budaya. Piagam Madinah merupakan perlembagaan bertulis pertama di dunia yang berjaya mengurus masyarakat majmuk sehingga Madinah menjadi sebuah negara yang disegani. Selain aspek kewarganegaraan, Piagam Madinah juga diyakini mengandungi ramuan yang mampu mengharmonikan hubungan antara kaum. Walau bagaimanapun, ia belum pernah disoroti secara kritikal dalam kajian-kajian semasa. Justeru, penulisan ini bertujuan untuk menyingkap beberapa panduan Islam dalam mewujudkan keharmonian kaum melalui Piagam Madinah yang dianggap sebagai perintis idea perlembagaan dalam sejarah Islam. Hasil kajian menunjukkan Islam tidak memusuhi kepelbagaian etnik. Sebaliknya ia dianggap sebagai salah satu pemangkin budaya, ekonomi dan politik negara bertamadun.
\end{abstract}

Kata kunci: keharmonian kaum, piagam Madinah, etnisiti, idea perlembagaan

\section{Sunnah Based Racial Harmony: A Study of the Medina Charter}

\begin{abstract}
Communities made up of diverse social backgrounds are often prone to conflict. This can lead to issues such as discrimination, fights, wars, oppression and so on. Therefore, social cohesion plays an important role in achieving harmony in a plural society. Yathrib (the name of Medina before the migration), for example, is engraved in the history of the Arabian Peninsula civilization as a 'conflict area' due to the ongoing fights and wars between the Aus and Khazraj. Prophet Muhammad SAW as the head of state has drafted the Medina Charter in an effort to manage the people of Medina who are different in race, language, religion and cultural customs. The Medina Charter was the first written constitution in the world to successfully manage a plural society until Medina became a respected nation. In addition to the aspect of citizenship, the Medina Charter is also believed to contain ingredients that can harmonize relations between races. However, it has never been critically highlighted in current studies. Thus, this writing aims to reveal some Islamic guidelines in creating racial harmony through the Medina Charter which is considered to be the pioneer of the idea of a
\end{abstract}


DOI: https://doi.org/10.47405/mjssh.v6i7.836

constitution in Islamic history. The results show that Islam is not hostile to ethnic diversity. Instead it is considered as one of the cultural, economic and political catalysts of a civilized nation.

Keywords: racial harmony, charter Medina, ethnicity, the idea of a constitution

\section{Pengenalan}

Kejadian manusia yang berbeza warna kulit dan keturunan, bangsa dan bahasa, budaya serta adat resam bukannya untuk menunjukan keangkuhan dan kesombongan antara mereka. Falsafah dan hikmah daripada kepelbagaian tersebut dinyatakan oleh Allah SWT sebagaimana firmanNya dalam surat al-Hujurat ayat 13 yang bermaksud:

"Wahai manusia, sesungguhnya Kami telah menciptakan kamu daripada lelaki dan perempuan serta Kami menjadikan kamu berbagai bangsa dan bersuku-puak, supaya kamu saling mengenali. Sesungguhnya semulia-mulia kamu di sisi Allah SWT ialah orang yang bertakwa. Sesungguhnya Allah Maha Mengetahui, lagi Maha Mendalam PengetahuanNya".

Menurut Hamka (1985:208), ayat ini menjelaskan bahawa Allah SWT menjadikan manusia berbagai bangsa dan bersuku-puak supaya manusia saling mengenali. Manusia digalakkan supaya mengenali asal-usul, asal nenek moyang, keturunan dan sebagainya. Kemuliaan di sisi Allah SWT adalah kemuliaan hati, budi, akhlak dan ketakwaan kepada Allah SWT. Ayat ini diturunkan bertujuan mengawal perasaan manusia yang menganggap diri mereka lebih baik daripada yang lain. Hal ini seiring dengan pandangan Ibn Kathir (2004:495-497) bahawa penciptaan manusia yang berbagai bangsa dan bersuku-suku supaya manusia dapat mengenali antara satu sama lain. Menurut Fathi Osman (1997:121) pula, ayat ini secara khusus meletakkan asas kemajmukan supaya manusia menjauhi konflik dan pengasingan. Manakala, kepelbagaian manusia dapat menggalakkan hubungan interaksi, kerjasama dan saling melengkapi.

\section{Madinah Sebelum Islam}

Perbincangan mengenai masyarakat Madinah sebelum dan selepas kedatangan Islam perlu dibicarakan kerana berlakunya perubahan cara hidup yang ketara antara dua tempoh masa tersebut. Menurut Wat (1956), pengetahuan tentang keadaan di Madinah sebelum Islam adalah penting untuk mendapatkan gambaran antara sebelum dan selepas kedatangan Nabi Muhammad SAW. Sebelum kedatangan Islam, pergaduhan dan peperangan kaum adalah perkara yang sering berlaku tetapi selepas kedatangan Islam amalan kerjasama menjadi asas dalam perhubungan masyarakat Madinah (Naeem, 1982).

Masyarakat Arab sebelum Islam khususnya di Tanah Hijjaz mempunyai struktur sosial yang mengatur pola perilaku, hubungan keluarga dan kelompok masyarakat (J. Suyuthi, 1993). Penduduknya terdiri daripada kaum Arab dan Yahudi. Kaum Arab tinggal di Makkah, Madinah dan Taif. Kaum Yahudi pula tinggal di Madinah dan sekitarnya. Dua rumpun ini berasal daripada ras Semit yang bermula daripada Nabi Ibrahim a.s. melalui dua puteranya iaitu Nabi Ishak a.s. dan Nabi Ismail a.s. Rumpun kaum Arab Makkah adalah melalui persemendaan antara Nabi Ismail a.s dan arab Jurhum. manakala rumpun kaum Yahudi melalui Nabi Ishak a.s. (Guillaume, 2004).

Madinah sebuah kota kecil dan penduduknya dianggarkan seramai 4000 hingga 5000 orang (Mat Saad Abd. Rahman, 1995:34). Dari segi politik, Madinah - sama seperti Makkah - tidak pernah mengenali perihal susunan bernegara kerana masyarakat Madinah pada waktu itu bergantung kehidupan dan keselamatan diri dan keluarga kepada sukuan kabilah (Afzalur Rahman, 1992). Sistem sosial mereka berasaskan sistem kesukuan kabilah atau puak iaitu setiap suku melindungi dan mempertahankan ahli masing-masing (Muhammad Al-Hasyimi, 2006:151). Terdapat juga masyarakat Madinah yang 
mengamalkan kehidupan nomad yang dikenali sebagai Arab Badwi (Zuhairi Misrawi, 2011:108; Naeem Siddiqi, 1982:14).

Penduduk Madinah ketika itu terdiri daripada pelbagai kaum, suku dan puak seperti kaum Arab terdiri daripada suku Aws dan Khazraj yang merupakan imigran dari Arab Selatan serta suku Arab lain yang menetap di Madinah (S. Abul, 1982). Menurut Ibn Sa'dal-Baghdadi, dalam suku Aus dan Khazraj terdapat lapan puak sebagaimana yang disebut dalam Piagam Madinah serta 33 kumpulan kecil yang bersama-sama dalam peperangan Badar (Watt, 1956:153).Kaum Arab ini berpegang kepada kepercayaan khurafat, menyembah berhala, menganut agama Yahudi dan Kristian. Manakala, kaum Yahudi yang menganut ajaran Nabi Musa a.s. dianggarkan berjumlah 20 suku dan suku yang terkenal ialah Bani Quraizah, Bani Nadhir dan Bani Qainuqa'(Mat Saad Abd. Rahman, 1995:34; J. Suyuthi Pulungan, 1993:39). Setiap kelompok tinggal di kawasan khas dan mereka jarang berinteraksi dalam masyarakat majmuk. Oleh sebab itu, perselisihan dan pergaduhan sering berlaku dalam kalangan mereka (Zuhairi, 2011).

Masyarakat Madinah mempunyai cara hidup tersendiri dan mempunyai ikatan sosial yang terpisah daripada satu kelompok dengan kelompok yang lain. Pada waktu itu, hubungan antara kaum Arab dengan Yahudi tidak tenteram kerana masing-masing menaruh minat untuk menjadi penguasa Madinah malah suku kaum Yahudi juga saling bermusuhan (Abul Hassan, 1983). Kaum Yahudi menguasai dan berpengaruh dalam pasaran ekonomi Madinah. Mereka mengamalkan riba dan pergadaian. Pergadaian bukan hanya pada barangan perdagangan malah melibatkan wanita dan anak kecil. Mereka juga mengaut keuntungan berlipat kali ganda sehingga menimbulkan perasaan benci kaum Arab terhadap kaum Yahudi (Shaikh Sofiy, 2011; Zuhairi, 2011; Abul Hassan, 1983).

\section{Madinah Selepas Islam}

Penghijrahan Nabi Muhammad s.a.w dan kaum Muhajirin mengubah komposisi penduduk Madinah menjadi tiga kelompok besar iaitu kaum Arab Mekah yang berhijrah bersama-sama Rasulullah SAW, kaum Arab Madinah dan Yahudi. Kaum Arab Mekah yang beragama Islam merupakan kaum pendatang dikenali sebagai Muhajirin manakala kaum Arab Madinah yang menganut Islam dikenali sebagai Ansar. Kelompok bukan Islam pula terdiri daripada dua golongan iaitu kaum Yahudi dan pengikut agama berhala dikenali sebagai wathaniyyin (Zainal, 1973; Mat Saad, 1995:36)

\section{Kesahan Piagam Madinah}

Sumber-sumber Sirah Rasul SAW menyebut, Nabi Muhammad SAW telah mengarah supaya ditulis satu persefahaman yang kemudiannya dikenali sebagai al-Wathīqat al-Madanīyah atau Șahīfat alMadīnah yang disebut sebagai Piagam Madinah. Ia telah dilaporkan dengan lengkap oleh Ibn Ishāā (1979), Abū 'Ubayd (t.t.) dan Ibn Zanjuyah (1986). Namun, Ibn Ishāa melaporkannya tanpa sebarang jalur. Terdapat kemungkinan beliau memperolehinya daripada tokoh riwayat zaman beliau iaitu alZuhrī memandangkan beliau adalah antara murid kanan al-Zuhri. Adalah berkemungkinan juga beliau memperolehnya daripada 'Uthmān bin Muḥammad bin 'Uthmān bin al-Akhnas bin Sharīq sepertimana yang dilaporkan oleh al-Bayhaqī (2003). Namun, laporan al-Bayhaqī hanya berkaitan dengan perjanjian antara kaum Muhajirin dan Ansar. Manakala, Abū 'Ubayd pula melaporkannya secara mursal. Melalui penelitian terhadap jalur-jalur yang melaporkan Piagam Madinah, ia tidak terlalu kuat untuk dijadikan asas hukum syarak. Walau bagaimanapun, ia sudah memadai untuk dijadikan bukti bagi kewujudan sesuatu peristiwa dalam sejarah (al- 'Umari, 2007).

Kewujudan Piagam Madinah turut dikuatkan apabila sebahagian subtopik atau kandungannya turut dilaporkan dalam al-Șaḥịhān (Ṣaḥịh al-Bukhārī dan Șaḥị̣ Muslim), Sunan Abū Dāwūd, Sunan alTirmidhī, Sunan al-Nasā̄ $\overline{1}$, Musnad Ahmad dan lain-lain sumber hadith yang muktabar dengan jalurjalur yang kuat dan șahịh. Contohnya, hadith riwayat Ali RA yang menjelaskan tentang pembayaran pampasan oleh suku kabilah dan pembebasan tawanan sebagaimana yang dilaporkan oleh al-Bukhārī (2002), Muslim (t.t) dan Abu Dāwūd (2009). Ia telah dijadikan sebagai asas hukum oleh para fuqaha' 
dalam kitab-kitab fiqh. Dalam rujukan sirah dan sejarah Islam menyebut Rasulullah SAW pernah mengadakan perjanjian dengan kaum Yahudi selain perjanjian yang melibat kaum muhajirin dan Ansar. Ketokohan al-Zuhrī selaku pelapor utama Piagam Madinah turut menguatkan lagi bukti kewujudannya. Persamaan laras bahasa antara Piagam Madinah dan surat-surat Rasulullah SAW kepada para pembesar seolah-olah menunjukkan Piagam tersebut ditulis pada zaman Nabi SAW (al'Umarī, 2007).

Sebahagian pengkaji berpendapat Piagam Madinah tidak pernah wujud dan riwayat mengenainya adalah palsu. Hal ini adalah disebabkan ia tidak pernah dilaporkan dalam kitab-kitab hadith șaḥị yang muktabar sungguhpun kandungannya adalah sangat penting. Selain itu, teks piagam yang sempurna telah dilaporkan oleh Ibn Isḥāq tanpa jalur. Walaupun Ibn Abi Khaythamah telah menyebut jalur Ibn Ishāâ, namun terdapat seorang perawi yang dinilai sebagai pemalsu hadith iaitu Kathīr bin Abd Allāh al-Muzanī. Adalah berkemungkinan Ibn Isḥāq melaporkan Piagam Madinah melalui jalur tersebut dan sengaja tidak menyebut jalurnya bagi mengelak riwayatnya ditolak.

Sebenarnya, terdapat tiga kemungkinan dalam menentukan sumber jalur bagi Teks penuh Piagam Madinah yang dilaporkan oleh Ibn Ishāq yang menjadi pertikaian golongan yang menolak sepenuhnya Piagam tersebut. Pertama, ia diperoleh daripada al-Zuhrī memandangkan Ibn Ishāq adalah antara murid kanan beliau. Kedua, ia diperoleh daripada 'Uthmān bin Muḥammad bin 'Uthmān bin alAkhnas bin Sharīq seperti yang dilaporkan oleh al-Bayhaqī. Ketiga, ia dilaporkan melalui jalur Kathīr bin Abd Allah al-Muzan̄̄. Justeru, menilai riwayat Ibn Ishāq sebagai palsu berdasarkan tiga kemungkinan di atas adalah kurang cermat.

Selain itu, Ibn Ishāq bukanlah satu-satunya sumber yang melaporkan Piagam Madinah. Ia juga turut dilaporkan oleh Abū 'Ubayd dan Ibn Zanjūyah. Kedua-dua riwayat ini masih boleh dijadikan asas dalam hal-hal selain hukum seperti penentuan tarikh, peristiwa dan lain-lain.

Dakwaan Teks Piagam Madinah tidak pernah dilaporkan dalam kitab-kitab hadith șahịh adalah tidak tepat disebabkan sebahagian daripadanya telah dilaporkan oleh al-Bukhāri, Muslim, Abu Dāwūd dan lain-lain. Ia juga dijadikan hujah oleh para fuqaha dalam buku-buku mereka. Justeru, dakwaan bahawa Piagam Madinah tidak pernah wujud dikira agak keterlaluan.

\section{Sejarah Penulisan Piagam Madinah}

Hakikatnya, Piagam Madinah mengandungi dua bahagian dan terdapat perselisihan dalam kalangan pengkaji tentang tarikh penulisan kedua-dua bahagian tersebut. Menurut Al-Umarī (2007), bahagian yang mengandungi perjanjian antara kaum Arab dan Yahudi telah ditulis sejurus ketibaan Rasulullah SAW ke Madinah. Sementara bahagian yang mengandungi perjanjian antara kaum Muhajirin dan Ansar telah ditulis selepas Perang Badr al-Kubrā.

Piagam ini merupakan perlembagaan bertulis yang pertama di dunia yang dirangka oleh Nabi Muhammad SAW sebagai panduan kepada masyarakat majmuk di Madinah (Watt, 1956; Muhammed Hamidullah, 1968; Zainal, 1973; AfzalurRahman, 1992; Roziah, 2004; Ahmad Ibrahim \& Dzafar ElQasimy, 1985). Menurut Watt (1956), Peters (1994) dan Ahmad Khairuddin (2007), Piagam Madinah merupakan dokumen yang autentik dan mempunyai kandungan yang sesuai dengan keadaan sosiologi dan sejarah pada zaman tersebut. Guillame (2004) menamakan Piagam Madinah sebagai Friendly Agreement dalam bukunya yang bertajuk The Life of Muhammad. Menurut Guillame (2004), piagam ini menekankan kehidupan berdampingan antara golongan Muhajirin dengan Ansar serta Yahudi. Golongan ini saling menghormati agama, melindungi hak milik dan mempunyai kewajipan yang sama dalam mempertahankan Madinah.

Piagam ini mengandungi 48 fasal dan ia dimulakan dengan lafaz Basmalah. Fasal 1 hingga 23 adalah mengenai hubungan antara kaum Muhajirin dan Ansar. Fasal 24 hingga 46 adalah mengenai hubungan antara kaum Muslimin dan Yahudi. Selebihnya adalah mengenai kedaulatan undang-undang. Pada awalnya, fasal-fasal dalam piagam ini terangkum kesemuanya dalam satu perenggan sahaja. Ia mula 
disusun dan dipecahkan kepada 47 tujuh fasal oleh Julius Wellhausen. Kemudian ia dipecahkan lagi kepada 52 fasal oleh Hamidullah (1987). Seterusnya Abd al-Aziz (2020) memperincikannya lagi kepada 63 fasal.

\section{Piagam Yang Mesra Hubungan Etnik}

Piagam Madinah dilihat sebagai perjanjian yang fleksibel dan mengalu-alukan kepelbagaian kaum dan agama. Hal ini disebabkan ia mengetengahkan istilah "ummah" dengan pengertian yang sangat luas dan rentas sempadan bangsa, kepercayaan agama dan negara (Qaradawi, t.t). Perkataan "ummah" disebut secara jelas sebanyak dua kali dalam Piagam Madinah selain istilah-istilah lain seerti dengannya. Dalam fasal-1 ketika menjelaskan perjanjian antara kaum Muslimin yang terdiri daripada penduduk asal kota Madinah dan golongan Muhajirin telah dinyatakan: "Ini adalah suatu ketetapan daripada Muhammad SAW iaitu berkaitan perjanjian di antara golongan mukmin dan Muslim dari kalangan Quraysh dan penduduk Yathrib serta orang-orang yang menyertai mereka dan berjuang bersama mereka: sesungguhnya mereka adalah "ummah" yang satu selain daripada sekalian manusia"

Dalam fasal 25(29), ketika menjelaskan perjanjian antara kaum Muslimin dan Yahudi dinyatakan:

"Sesungguhnya Yahudi Bani 'Awf adalah "ummah" bersama kaum mukmin. Orang Yahudi berhak mengamalkan agama mereka dan kaum yang beriman (orang Islam) juga berhak mengamalkan agama mereka. Melainkan sesiapa yang berbuat zalim atau dosa dari kalangan mereka, sesungguhnya dia hanya membinasakan dirinya dan ahli keluarganya".

Selain perkataan "ummah", terdapat banyak kabilah dan suku kaum yang disebut dalam Piagam Madinah yang menunjukkan ia mengambil kira maslahat pelbagai golongan yang mendiami kota Madinah ketika itu.

\section{Pengertian Ummah Dalam Piagam Madinah}

Berikut adalah beberapa pengertian "ummah" yang diketengahkan dalam Piagam Madinah sebagaimana yang dibincangkan oleh Qaradawi (t.t):

\section{Ummah Berakidah}

Fasal 15(16-17) dalam Piagam Madinah menyatakan kaum mukmin adalah penolong antara satu sama lain. Ia membawa maksud mereka adalah satu ummah dalam berhadapan dengan golongan yang berlainan kepercayaan daripada mereka. Kesatuan ini boleh dilihat melalui kebersamaan dalam menghadapi musuh, komitmen membayar pampasan kerugian nyawa akibat peperangan, kepatuhan kepada al-Quran dan Sunnah dalam mencari solusi ketika berlaku perselisihan. Hal ini telah diperincikan melalui fasal 17(19) hingga 23(27). Ummah melalui dimensi ini tidak terikat dengan sempadan negara atau dengan kata lain, kaum mukmin yang berada di luar Madinah mempunyai hak ke atas saudara seakidah mereka yang berada dalam kota Madinah. Walau bagaimanapun, hak golongan Muslim dan bukan Muslim yang berstatus warganegara Madinah adalah lebih diutamakan berbanding golongan mukmin berada di luar kota Madinah (Qaradawi, t.t).

\section{Kesefahaman Politik}

Fasal 25(29) hingga 35(40) dalam Piagam Madinah menyatakan orang Islam dan kaum Yahudi yang terdiri daripada pelbagai suku adalah satu umat. Setiap mereka memiliki agama masing-masing dan berhak mengamalkannya. Mereka saling bantu membantu melainkan dalam perkara kezaliman. Dalam fasal 25(29) dan 31(35) dinyatakan, barang siapa sama ada Muslim atau Yahudi melakukan kezaliman, dia dan kaum keluarganya adalah bertanggungjawab menanggung ganti rugi atau pampasan. Ummah 
dari dimensi ini melangkaui batasan agama tetapi ia masih terikat dengan maslahat rakyat di bawah satu kepimpinan.

\section{Negara Bangsa}

Kewarganegaraan adalah bentuk hubungan antara individu dan negara sebagaimana yang ditetapkan oleh undang-undang negara tersebut (Abd al- 'Azīz, 2020). Dalam semua keadaan, sempadan negara adalah asas kewarganegaraan masa kini (Qaradawi, t.t). Istilah warganegara tidak pernah digunakan dalam teks klasik Islam. Namun, maksudnya, hukum-hukum dan formula mengenainya sarat dalam perbincangan sarjana-sarjana Islam silam. Dalam konteks Piagam Madinah, ia diungkapkan dengan istilah "ummah". Maksud ini jelas dilihat melalui fasal 1 dan 2 dalam Piagam tersebut. Dalam fasal-1 dinyatakan perjanjian tersebut melibatkan orang Islam dari kalangan Quraysh, penduduk Yathrib dan golongan yang menyertai, bergabung serta berjuang bersama mereka di Bumi Madinah. Dalam fasal-2 dinyatakan mereka yang disebut dalam fasal-1 adalah satu ummah dan bersatu dalam menghadapi golongan selain mereka. Kelayakan seorang Muslim memperoleh hak-hak yang dinyatakan dalam Piagam Madinah tertakluk kepada syarat yang ditetapkan iaitu dia mestilah seorang warganegara yang memberi komitmen kepada negara dengan cara berjihad. Setiap Muslim adalah sebahagian daripada ummah. Namun, seseorang itu perlu berhijrah atau menetap dalam negara Islam (al-Dawlat alIslāmīyah) untuk diiktiraf sebagai sebahagian daripada ummah tersebut. Mempertahan maslahat dan hak-hak warganegara sama ada Muslim atau bukan Muslim adalah lebih utama berbanding mempertahankan hak seorang Muslim yang tertindas tetapi di luar kota Madinah. Hal ini adalah selari dengan maksud ayat-72 daripada Surah al-Anfāl (Qaradawi, t.t).

\section{Ummah Berkebajikan}

Antara ciri-ciri utama masyarakat Islam ialah saling membantu dan menampung antara satu sama lain. Mereka bersedia menjadi penjamin dalam hal-ehwal dunia mahupun akhirat ('Alī Nadim, 2010). Konsep bantu-membantu ini persis dengan sistem takaful atau jaminan sosial yang wujud pada hari ini. Komuniti yang bersatu di bawah satu wadah seperti keturunan, tempat tinggal, pekerjaan, organisasi dan yang seumpamanya akan bekerjasama antara satu sama lain dan menikmati hak dan tanggung jawab yang sama. Hal ini telah disebut secara kerap dalam Piagam Madinah dan menjadi batu asas pembentukan masyarakat Madinah. Nama-nama puak dan suku telah disebut secara jelas dalam fasal 3(2) hingga 11(10) seperti Muhajirin, Bani 'Awf, Bani Harith, Bani Sā'idah, Bani Jusham, Bani Najjār, Bani 'Amr, Bani al-Nabīt dan Bani Aws. Mereka adalah berkewajipan menanggung pampasan atau bayaran ganti rugi disebabkan kesalahan yang dilakukan oleh salah seorang daripada puak atau suku mereka. Selain itu, mereka juga harus membebaskan mana-mana ahli mereka yang ditawan atau dalam kesempitan sepertimana yang dianjurkan oleh Islam. Dalam fasal-37 dinyatakan setiap kaum Yahudi dan begitu juga orang Islam bertanggung jawab menanggung sesama mereka. Mereka harus bekerjasama menentang sesiapa sahaja yang melanggar segala yang termaktub dalam Piagam. Mereka harus saling nasihat menasihati, membela, berbakti dan tolong menolong dalam perkara kebaikan. Dalam fasal-44 dinyatakan mereka berkewajipan menentang mana-mana golongan yang menyerang dan berusaha merampas bumi Madinah.

Jelas, istilah ummah yang dinyatakan dalam Piagam Madinah adalah sinonim dengan istilah warganegara yang diguna pakai secara berleluasa pada hari ini. Setiap warganegara atau mereka yang disifatkan sebagai ummah adalah berkewajipan menunaikan tanggungjawab sebagaimana yang dinyatakan dalam piagam bagi menjamin maslahat rakyat seluruhnya. Mereka juga berkewajipan mempertahankan tanah air mereka daripada sebarang anasir yang merosakkan hubungan kaum. Justeru, tidak hairan sesetengah pengkaji menyifatkan Piagam Madinah sebagai sebuah perjanjian yang melambangkan kepimpinan yang komprehensif dan merealisasikan keperluan masyarakat berbilang kaum ('Awn al-Rafĩq, 2009). Hal yang demikian dapat dilihat melalui pengiktirafannya kepada bukan Muslim sebagai ummah dalam masyarakat Muslim dan di bawah naungan sebuah negara (Watt, 1956; al-Ghazali, 2007; Izzuddin, 2008). Merealisasikan maksud ummah seperti yang dinyatakan dalam Piagam Madinah dilihat mampu meleburkan jurang perkauman (al-Būṭ̂̄, 2006). 


\section{Nilai-Nilai Murni}

Nilai-nilai murni yang menjadi teras masyarakat bertamadun amat ditekankan dalam Piagam Madinah seperti tolong menolong sesama masyarakat, menghormati perasaan, anutan orang lain, bertolak ansur dalam hal-hal yang dibenarkan syarak dan merujuk segala perselisihan kepada kuasa yang tertinggi iaitu Rasulullah SAW. Madinah adalah negara masyarakat Muslim dan bukan Muslim yang mendaulatkan syariat Islam (Qaradawi, t.t). Justeru, adalah tidak wajar bagi seorang Muslim menzalimi seorang bukan Muslim yang diperakui haknya oleh negara (al-Sibā̄î, 1985). Nabi Muhammad SAW telah berjaya menetapkan undang-undang yang berasaskan toleransi pada waktu yang rata-rata masyarakatnya dikuasai oleh semangat asabiah dan peraturan-peraturan yang menindas golongan yang lemah (al-Ghazālī, 2007) dalam masa yang sama, seluruh masyarakat Madinah memperakui kedudukan dan autoriti Baginda sebagai rujukan yang tertinggi seperti yang telah dinyatakan dalam fasal-23(28) dan perkara-42(53).

\section{Prinsip Keadilan}

Prinsip keadilan bertujuan membebaskan manusia daripada kezaliman dan penindasan (Nik Abdul Aziz Nik Mat \& Azrul Hakim Suradi, 2012). Keadilan yang dilaksanakan oleh Rasulullah SAW berjaya mewujudkan kestabilan sosiopolitik Madinah (Naeem Siddiqi, 1982). Prinsip ini merupakan matlamat perjuangan Rasulullah SAW sebagaimana firman Allah SWT yang bermaksud:

"Kami mengutuskan para Rasul bagi membawa bukti-bukti yang nyata. Kami turunkan bersama mereka kitab dan neraca keadilan supaya manusia dapat melaksanakan keadilan". (Al-Hadid, 57:25)

"Allah SWT menyuruh kamu menyampaikan amanah pada yang berhak menerimanya dan apabila kamu menetapkan hukum antara manusia, hendaklah kamu menetapkan dengan adil. Sungguh Allah SWT sebaik-baik yang memberi pengajaran kepadamu. Allah SWT Maha Mendengar lagi Maha Melihat". (AlNisa', 4:58)

Menurut al-Qaradhawi (1999), Allah SWT menjadikan manusia sebagai khalifah agar manusia melaksanakan kebaikan dan menjauhi kemungkaran. Oleh sebab itu, Islam menekankan prinsip keadilan dalam kehidupan manusia. Menurut Syed Hussein Al-Attas (1996), keadilan sosial merupakan tuntutan mutlak yang diperlukan dalam sesebuah negara bagi menjamin hak dan kepentingan masyarakat.

Oleh sebab itu, Rasulullah SAW menggubal Piagam Madinah berasaskan prinsip keadilan. Dalam Fasal 21 misalnya menerangkan tentang kesalahan membunuh yang dilakukan tanpa bukti yang kukuh akan dibalas dengan hukuman qisas kecuali walinya setuju untuk menerima ganti diat. Hukuman qisas dan diat bertujuan menjaga hak manusia untuk hidup di samping menjaga kerukunan dan menjamin keamanan (Ahmad Ibrahim \& Dzafar El-Qasimy, 1985). Fasal 21 menyebut bahawa:

"Barang siapa membunuh dengan sewenang-wenangnya akan seorang mukmin dengan tidak ada bukti yang cukup hendaklah dihukum bunuh balas kecuali jika dipersetujui oleh wali yang kena bunuh menerima ganti darah. Orang Mukmin hendaklah bersatu mengutuk perbuatannya itu, bahkan tidak harus bagi mereka melainkan menegakkan terhadapnya".

Selain itu, prinsip ini juga dapat dilihat dalam Fasal 22 yang menjelaskan tanggungjawab setiap anggota masyarakat supaya tidak membantu dan memberi perlindungan kepada seseorang yang melakukan kesalahan. Ahli masyarakat yang memberi perlindungan kepada pesalah akan dianggap bersalah dan menerima kemurkaan Allah SWT di akhirat kelak. Malah, ganti rugi untuk melepas diri daripada menerima hukuman juga tidak diterima. Fasal 22 menyebut bahawa: 
"Bahawa tidak harus bagi orang mukmin yang mengakui isi kandungan Piagam ini dan percaya kepada Allah SWT dan Hari Kemudian menolong orang yang mencabul atau melindungi orang tersebut. Barang siapa menolong orang tersebut maka ke atasnya laknat Allah SWT dan kemurkaan-Nya pada Hari Kiamat kelak. Dan tidak akan diterima daripadanya sebarang tebusan dan juga taubat".

Fasal ini menunjukkan prinsip keadilan dan kedaulatan undang-undang diberi jaminan sepenuhnya. Menurut Abdul Monir (1986), masyarakat Madinah berhak mendapat perlindungan perundangan dan keadilan sebagaimana tercatat dalam Fasal 36 (b) dan 47. Fasal 36 (b) yang menjelaskan bahawa hukuman akan dikenakan mengikut kesalahan yang dilakukan tanpa mengira kedudukan. Hukuman akan dikenakan ke atas diri dan keluarga namun golongan yang dizalimi tidak dikenakan hukuman. Fasal 36 (b) menyebut bahawa:

"Tidak boleh disekat daripada membalas kecederaan yang dilakukan oleh manamana orang ke atas dirinya. Barang siapa membuat kejahatan maka balasannya adalah ke atas diri dan keluarganya kecuali orang yang dizalimi. Bahawa Allah SWT akan melindungi orang yang menghormati piagam ini”.

Dalam Fasal 47 menyatakan bahawa:

"Bahawa Piagam ini tidak boleh dipakai bagi melindungi orang yang zalim dan bersalah. Mulai dari saat ini barang siapa berpergian dari Madinah atau menetap di dalamnya adalah terjamin keselamatannya kecuali orang yang zalim atau yang bersalah. Dan bahawa Allah SWT merestui setiap orang yang membuat kebajikan dan bertakwa serta Muhammad SAW hendaklah diakui Pesuruh Allah SWT".

Seterusnya, prinsip ini juga dapat dilihat dalam Fasal 37 (b) yang menjelaskan bahawa seseorang tidak akan dihukum kerana kesalahan yang dilakukan oleh individu lain. Seseorang yang melakukan kesalahan perlu bertanggungjawab manakala individu yang dizalimi perlu diberi pertolongan sewajarnya (Ahmad Ibrahim \& Dzafar El-Qasimy, 1985). Fasal 37 (b) menyebut bahawa:

"Mana-mana orang tidak boleh dianggap bersalah kerana kesalahan yang dilakukan oleh sekutunya dan pertolongan hendaklah diberi kepada orang yang dizalimi".

Fasal-Fasal ini membuktikan bahawa Rasulullah SAW melaksanakan keadilan kepada seluruh masyarakat Madinah tanpa mengira perbezaan latar belakang sosial. Prinsip ini bagi mewujudkan keseimbangan sosial untuk mewujudkan negara yang aman dan harmonis. Menurut S. Abul A'la Maududi (1986), hak masyarakat Islam dan bukan Islam terjamin di bawah pemerintahan Islam.

\section{Kesimpulan}

Berdasarkan kepada perincian yang lalu, Piagam Madinah didapati berjaya mewujudkan suasana masyarakat madani yang harmoni disebabkan ia mengandungi teras-teras perpaduan seperti piagam yang mesra hubungan etnik, penerapan makna ummah yang luas, jaminan sosial, nilai-nilai murni dan prinsip keadilan. Justeru, masyarakat majmuk dalam kota Madinah tidak dilihat sebagai penghalang kemajuan sebaliknya ia menjadi aset kekuatan dan kejayaan masyarakat madani.

\section{Rujukan}

Abd al-'Azīz Muḥammad al-Khalaf (2020). Wathīqat al-Madīnah wa Dawruhā fì Irsā' alMuwātanah. roayamedia.org.

Abdul Monir Yaacob (1986). Hak Asasi Manusia Menurut Islam: Sejarah dan Konsepnya. Bangi: Universiti Kebangsaan Malaysia. 
Abul Hassan Ali Al-Hasany An-Nadwy (1983). Riwayat Hidup Rasulullah SAW (Terj. Bey Ariffin \& Yunus Ali Muhdhar). Singapura: Pustaka Nasional.

Afzalur Rahman (1992). Ensiklopedia Sirah, Sunah, Dakwah dan Islam Jilid 1(Terj. Zaharah Salleh: Muhammad S.A.W. Encyclopaedia of Seerah, Volume 1). Kuala Lumpur: Dewan Bahasa dan Pustaka.

Ahmad Barakat (1979). Muhammad and the Jews. New Delhi: Vikas Publishing House.

Ahmad Ibrahim \& Dzafar El-Qasimy (1985). Piagam Madinah: Pandangan dan Ulasan (Terj. Abu Bakar Hamzah). Kuala Lumpur: Gelanggang Kreatif.

Ahmad Khairuddin (2007). Konstitusi Madinah Latar Belakang dan Dampak Sosialnya. Al-Banjari, 5(9), 1-20.

Al-Baghdādī, Abū 'Ubayd (t.t). Al-Amwāl. Beirut: Dār al-Fikr.

Al-Bayhaqī, Ahmad bin Husayn (2003). Al-Sunan al-Kubrā. Beirut: Dār al-Kutub al- 'Ilmīyah.

'Alī Nadīm al-Himșī (2010). Al-Islāmīyūn wa al-Mushārakah fi Mujatam' Mutanawwi ': Mafhūm alMuwātanah fi al-Sharī'at al-Islāmīyah, Șahīfat al-Madīnat al-Munawwarah Namūzajan. Almaaref.org.

Al-Imam Al-Bukhary (2009). Terjemahan Hadis Shahih Bukhari Jilid I, II, III \& IV (Terj. H. Zainuddin Hamidy et al.). Kuala Lumpur: Klang Book Centre.

Al-Muțtalibī, Muḥammad bin Isḥāq (1978). Sirat Ibn Isḥāq. Beirut: Dār al-Fikr.

Al-Naysābūrī, Muslim bin al- Ḥajjāj (t.t). Saḥịh Muslim. Beirut: Dār Ihyā̄' al-Turāth al-'Arabī.

Al-Sijistān̄̄, Abu Dawūd (2009). Sunan Abu Dāwūd. Beirut: Dār al-Risālat al- 'Ālamī.

Al- 'Umarī, Akram Ḍiyā' (2007). Al-Sirat al-Nabawīyat al-Sahīh h̄hh. Riyadh: Maktabat al- 'Ubaykān.

Che Bakar Che Mat et al. (2007). Pengenalan kepada Sistem Kemasyarakatan dan Kenegaraan Islam. Shah Alam: Pusat Penerbitan Universiti (UPENA).

Guillaume, A. (2004). The Life of Muhammad. Karachi: Oxford University Press.

Hamka (Haji AbdulMalik AbdulKarim Amrullah) (1985). Tafsir Al-Azhar Juzu' 10-11-12. Jakarta: Pustaka Panjimas.

Ibn Ishaq (1970). Sirat Rasulullah (Terj. Alfred Guillaume: TheLife of Muhammad). Lahore: Oxford University Press.

Ibn Zanjuyah, Humayd bin Makhlad (1986). Al-Amwāl. Saudi Arabia: Markaz al-Malik Fayṣal.

Ibnu Khaldun (1993). Mukadimah Ibn Khaldun (Terj. Dewan Bahasa dan Pustaka). Kuala Lumpur: Dewan Bahasa dan Pustaka.

Izzuddin (2008). Konsep Ummah dalam Piagam Madinah. Jurnal Darussalam, 7(2), 109-122.

J. Suyuthi Pulungan (1993). Prinsip-Prinsip dalam Perlembagaan Madinah ditinjau dari Pandangan Al-Qur'an. Disertasi Doktor Falsafah, IAIN Syarif Hidayatullah Jakarta.

Mat Saad Abdul Rahman (1995). Kedudukan Masyarakat Bukan Islam dalam Sejarah Pemerintahan Islam. Dlm. Pemerintahan Islam dalam Masyarakat Majmuk. Kuala Lumpur: Institut Kefahaman Islam Malaysia.

Muhammad Al-Ghazaliy (1997). Fiqhus Sirah: Menghayati Nilai-Nilai Riwayat Hidup Muhammad Rasulullah SAW (Terj. Abu Laila \& Muhammad Tohir). Klang: Klang Book Centre.

Muhammad Al-Hasyimi Al-Hamidi (2006). Sirah Nabawiyah: Muhammad for the Global Village (Terj. Zulfakar Ali \& Alimin Kuto Al-Madjid). Jakarta: Rabitha Press.

Muhammad Ḥamīd Allah al-Ḥaydar Ābādī (1987). Majmū 'at al-Wathā ìq al-Siyāsīyah li al- 'Ahd alNabawī wa al-Khilāfat al-Rashīdah. Beirut: Dār al-Nafāis.

Muhammad Sa‘id Ramadan Al-Buti (1997). Fiqh Al-Sirah Jilid 2 (Terj. Mohd. Darus Sanawi ‘Ali). Shah Alam: Dewan Pustaka Fajar.

Muhammed Hamidullah (1968). The Muslim Conduct of the State. Lahore: Ashraf.

Mustafa Al-Siba'ei (1985). Al-Sirah Al-Nabawiyyah (Terj. Nabhan Hussin: Al-Sirah Al-Nabawiyyah Durus Wa'ibar). Shah Alam: Dewan Pustaka Fajar.

Mustafa Ramadhan (1991). Inti sari Seerah Muhammad bin Abdullah SAW. Kuala Lumpur: A.S Noordeen.

Naeem Siddiqi (1982). Muhammad Membentuk Ummah (Terj. Mustaffa Ramadhan: Muhammad the Benefactory of Humanity). Pulau Pinang: Concentration Book Centre.

Peters, F. E. (1994). Muhammad and the Origins of Islam. New York: State University of New York Press.

Qaradawi, Yusuf (t.t). Al-Wațan wa al-Muwātanah fì Ḍaw`al-Uṣūl al- 'Aqadīyah wa al-Maqāṣid alShar '̄yah. Egypt: Dār al-Shurūq. 
DOI: https://doi.org/10.47405/mjssh.v6i7.836

S. Abul Hasan Ali (1982). Muhammad Rasulullah. The Apostle of Mercy (Terj. Mohiuddin Ahmad). Lucknow, India: Academy of Islamic Research \& Publications.

Saari Sungib (2013). Rahsia-Rahsia Besar disebalik Sirah Rasulullah SAW. Selangor: Kemilau Publika.

Shaikh Sofiy Al-Rahman Al-Mubarakfuri (2011). Sirah Rasulullah SAW (Terj. Mohd Darus Senawi Ali: Al-Raheeq Al-Makhtum). Selangor: Crescent News (K.L) \& Kumpulan Usahawan Muslim.

Shamsul Amri Baharuddin (Ed.) (2007). Modul Hubungan Etnik. Putrajaya: Universiti Teknologi Mara (UPENA).

Sosrodirdjo, H. R. M. (1988). Ensiklopedia Istilah Agama Islam. Kuala Lumpur: Golden Books Centre.

Watt, W. M. (1956). Muhammad at Medina. London: Oxford University Press.

Zainal Abidin Ahmad (1973). Piagam Nabi Muhammad SAW: Konstitusi Negara Bertulis Pertama di Dunia. Jakarta: Bulan Bintang.

Zaleha Embong (2016). Ta'awun Piagam Madinah Dalam Pembangunan Komuniti Majmuk di Kawasan Rukun Tetangga Timur Laut dan Barat Daya, Pulau Pinang. Tesis Doktor Falsafah.Universiti Sains Malaysia. Tidak diterbitkan. 